\title{
CRIMINALITY AND THE CANADIAN ANTI-COMBINES LAWS
}

\author{
BRUCE C. MCDONALD*
}

\section{INTRODUCTION}

Considerable attention has been devoted, over the course of the last seventy-five years, to the selection of legal controls designed to secure such economic structure and behaviour as is deemed politically desirable in Canada. Increasing concentration of private wealth and industrialization continuously make the matter more complex and yet more urgent.

The Canadian Parliament long ago decided that corporations and businessmen can and sometimes do act in socially undesirable ways in regard to the structural and behavioural aspects of a competitive economy. ${ }^{1} \quad$ A difficult legal problem is the finding of the most appropriate remedy, or combination of remedies, in view of the various desired objectives.

Laws are required, not only as an agreed statement of social objectives, but also as a means for ensuring those goals. The law furnishes a wide variety of forms of control, each designed to accomplish certain types of results and each having consequent limitations upon its capabilities.

The control of combines and unfair trade practices in Canada has fallen to the criminal law exclusively. Combines law originated as criminal law for natural "social" reasons in 1889 , but remains criminal for what may well be misconceived constitutional grounds. The object of this article is to examine the value of the criminal law as a regulatory tool for combines problems. The subject will be treated with a view to general criminal law concepts, followed by an analysis of the operation of leading criminal law principles in combines cases.

A brief description of the substantive portions of the Combines Investigation Act ${ }^{2}$ will assist those not familiar with its proscriptions. The Act embodies an attempt to define and ensure a basically competitive environment in which certain types of enterprise are to function. As a criminal statute, it endeavours to accomplish its object by prohibiting certain classes of restraints upon competition. Part V of the Act contains the substantive offences, which are, essentially, conspiracies (to fix prices, limit production, and so on), mergers, monopolies, price discrimination, predatory pricing, rebate differentials, misleading advertising, and resale price maintenance. Although some formal remedies under the Act may be applied without regular criminal procedure ${ }^{3}$ and

- Assistant Professor. Faculty of Law, Queen's University. This article is part of a thesis on combines remedies written in partial fulfillment of the requirements for the degree if S.J.D. at The University of Michigan.

1 The original combines legislation is (Can.) 1889, c. 41. Parliament had shown some concern for a decade prior to this, but had discussed the issue in terms of tariff change.

2 until 1888. 1960-61, c. 42; and (Can.) 1962-63, c. 4.

$3 \mathrm{~S}$. 31 (4) requires that proceedings by information of an Attorney-General under $s .31$ "shall be tried by the court without a jury, and the procedure applicable in injunction proceedings in the superior courts of the province shall, in so far as possible, apply." The Minister of Justice has suggested that the ordinary laws of evidence applicable in criminal proceedings would obtain for section $31(2)$, and that section 31 (2) was designed for the more dubious cases. See House of Commons Debates, 1960, pp. 6939-40. How the courts will treat the section has not yet become clear, since there have been no contested actions under section 31 (2). 
others without any court proceedings whatever, ${ }^{+}$the substantive offences are indictable. The sole exception is the summary offence of misleading advertising in relation to the price of an article. ${ }^{5}$

Mergers and agreements between companies are natural activities and are frequently socially beneficial. Since the basic values of the combines legislation appear to be economic in nature, flexible, extra-legal criteria have had to be written into the statute to accommodate desirable business phenomena in terms of optimal allocation of resources, use of capacity, and so on. This legislative problem and its solution are evident from the current proscriptions respecting mergers, monopolies, and conspiracies:

S.2(e) 'merger' means the acquisition by one or more persons, whether by purchase or lease of shares or assets or otherwise, of any control over or interest in the whole or part of the business of a competitor, supplier, customer or any other person, whereby competition

(i) in a trade or industry,

(ii) among the sources of supply of a trade or industry,

(iii) among the outlets for sales of a trade or industry, or

(iv) otherwise than in subparagraphs (i), (ii) and (iii),

is or is likely to be lessened to the detriment or against the interest of the public, whether consumers, producers or others;

S.2(f) 'monopoly' means a stiuation where one or more persons either substantially or completely control throughout Canada or any area thereof the class or species of business in which they are engaged and have operated such business or are likely to operate it to the detriment or against the interest of the public, whether consumers, producers or others, but a situation shall not be deemed a monopoly within the meaning of this paragraph by reason only of the exercise of any right or enjoyment of any interest derived under the Patent Act, or any other Act of the Parliament of Canada.

[Emphasis added.]

S.32(1) Everyone who conspires, combines, agrees or arranges with another person

(a) to limit unduly the facilities for transporting, producing, manufacturing, supplying, storing or dealing in any article,

(b) to prevent, limit or lessen, unduly, the manufacture or production of an article, or to enhance unreasonably the price thereof,

(c) to prevent, or lesson, unduly, competition in the production, manufacture, purchase, barter, sale, storage, rental, transportation or supply of an article, or in the price of insurance upon persons or property, or

(d) to restrain or injure trade or commerce in relation to any article,

is guilty of an indictable offence and is liable to imprisonment for two years. [Emphasis added.]

As an engine of social control, there are two chief reasons for selecting the criminal process. Firstly, the philosophy of the criminal law and the function and capacity of the criminal penalty may offer the most effective safeguard for the relevant public interest. Secondly, the procedural safeguards which are stationed around the criminal law may be desired as part of the sanctioning process. These two factors are necessarily related.

4 The Governor in Councll may, by s. 29 , adjust the duty on an article if it is satisfied, as a result of an inquiry under the Act, that certain specified criteria have been met. The real effect of this section is none too clear.

s S. $33 \mathrm{C}$. 


\section{COMBINES AND GENERAL CONCEPTS OF CRIMINAL LAW}

\section{General}

The traditional concern of the criminal law has been for the health and safety of the bodies and minds of the people who compose society. It has also dealt with some violations of the property rights of individuals, and with morally blameworthy exploitation of individuals. The underlying criteria derive from a principle of efficacy in the orderly functioning of society as a collective unit. This is the meaning of the familiar concept of the King's Peace. The Supreme Court of Canada has described the object of the criminal laws as follows:

They are concerned primarily not with rights, with their creation, the conditions of their exercise, or their extinction; but with some evil or some menace, moral or physical, which the law aims to prevent or suppress through the control of human conduct. ${ }^{\mathrm{C}}$

Economic crimes do not have to be directed at private persons. Income tax evasion and breaches of securities regulations usually involve moral considerations, and undermine the orderly supervision of society in a more direct way than do combines offences. The criminal law is also utilized to help secure integrity and responsibility in government and public administration, but in this area the offences are limited to easily definable acts which involve moral fault. ${ }^{7}$

The social problem of combines offences comes near to this latter area, since it also involves socially undesirable conduct and consequences occurring at a high level of organization and influence. The economic consequences are frequently colossal, even though perhaps thoroughly diluted in time and space. To what extent may the community, by the threat and penalties of the criminal law, effectively repudiate undesirable combines activity?

Since, to a large extent, the relevant public interest or interests can only be evident from the deliberations of Parliament, initial recourse must be had, in answering this question, to the original combines debates of 1888,1889 , and 1890 . Those debates illustrate a general agreement that combines should be suppressed; but, at the same time, disclose a vigourous dispute over the appropriate means of suppression.

The debates are characterized by moralistic overtones indicated by such phrases as "a crying and growing evil,"s "iniquitious," "per nicious," and "illegitimate." This appears to have been inspired by apprehension and alarm over the activities of the robber barons in the United States; and, indeed, our legislation was partially influenced by the reactions in the New York State legislature to that problem. ${ }^{10}$ Consequently, the members were naturally motivated by a rather personalized level of concern, and experienced little difficulty in equating the nature

6 Re Combines Investigation Act and S. 498 of the Criminal Code, [1929] 2 D.L.R. 802 (Duff, J., as he then was). Although the Court found the legislation to be within the criminal head of federal jurisdiction, this appeared to be on the basis that the legislation dealt with morally blameworthy practices "calculated . . . to limit competition and produce the evil of high prices." (Id., at 896).

It might be stated here, for the benefit of readers unfamillar with the Canadian law of competition, that all cases cited in this paper are combines cases, unless it is stated otherwise. The desire to avoid issues of substantive law has obviated any necessity for otherwise. The desire the facts involved in the cases.

7 See, generally, Criminal Code, Part III.

8 House of Commons Debates, 1888, pp. 34-35.

9 House of Commons Debates, 1889, p. 1111

10 House of Commons Debates, 1888, p. 29. 
of the social problem with that of common theft. Although the members, of course, appreciated the legal device utilized by the Carnegies, Rockefellers, and Morgans; they easily pierced its façade to uncover the dominating personalities holding extensive personal financial resources and control. They saw smaller models of the American trusts germinating in Canada in cotton, flour, sugar, rubber, ${ }^{11}$ and especially in coal. ${ }^{12}$

Parliament's disapproval, centred as it was upon the evil-doer as much as upon the evil itself, militated against the use of the tariff, which was the only alternative remedy seriously considered at the time. Of course, debate on this aspect was also highly political, as the National Policy included a high protective tariff to encourage development of Canadian industry. The government of the day prevailed in its opinion that private opportunities to enter trades could be better ensured by using the criminal remedy within the protective tariff system to sever the cancerous growth of combines from an otherwise healthy commercial society.

Other factors bore upon the selection of a criminal remedy. In the late nineteenth century the Canadian Parliament was consciously attempting to avoid any appearance of class legislation, ${ }^{13}$ and criminal legislation already proscribed certain activities of trade unions acting in restraint of trade. ${ }^{14}$ Also, of course, the government advocates regarded the statute as declaratory of the common law of criminal conspiracy, which they felt obtained at the time. ${ }^{1 .}$ This created some confusion in the minds of not a few of the members, who felt that if such were the case a statue was unnecessary.

Even among those who agreed that Parliament ought "to attack and destroy the evils which are arising to the community at large from combinations" were found opponents to the idea of a criminal sanction. The main objections were that the men involved were not of criminal characters, ${ }^{16}$ and that the law would necessarily entail a vague proscription of conduct for which a criminal penalty was inappropriate. ${ }^{17}$ These criticisms were directed, not in favour of an alternative form of judicial supervision, but rather in support of the case for tariff removal.

Little consideration was given by Parliament to any necessity for general public comprehension and disapproval of combines. This was generally assumed. Publicity, which is, of course, a necessary part of the criminal process, was to cure any public ignorance of hidden evils.. ${ }^{18}$

It is not to be concluded, however, that Parliament approached the use of the criminal sanction in a scientific manner. It was largely for political reasons, including the various ones here outlined, that our com-

11 Id., at 24.

12 Id., at 1544 .

13 See, for example, the debate on The Breaches of Contracts Bill in House of Commons Debates, 1877, pp. 855-74.

1. An Act Respecting Offences Against the Person, (Can.) 1869, c. 20, s. 42. In this connection it is interesting to note that the administration of the combines legislation was charged to the Minister of Labour until the 1944-45 fiscal year, when it was transferred to the Department of Justice.

1: See House of Commons Debates, 1889, p. 1113 (Mr. Wallace) and p. 1428 (Hon. Mr. Thompson, the Minister of Justice). For a critical appraisal of the merits of this view see Gosse, The Law on Competition in Canada, Chapter II (1962).

1i. House of Commons Debates, 1889, p. 32 (Mr. Lister).

17 Id. at 1115 (Mr. Mills).

1 s Id., at 1443. 
bines statute originated as criminal legislation. ${ }^{10}$ The various social injuries were not articulately itemized, but included the moral threat, stealing by means of charging artificially high prices, and a restriction upon the right of every man to seek his own vocation independent of the economic dictation of others.

\section{Public Interest and Purpose}

The criminal law is distinguished from most civil law partially by the nature of the public interest it is designed to secure. "Public interest," being the object of all legislative activity, is a phrase which only gains meaning when analyzed in context. The apparent emphasis in 1889 was upon the individuality of the victim and, more significantly, that of the offender. The cases and other public pronouncements over the course of the development of the combines law in Canada indicate a distinct shift toward a general concern for the economy as a whole. In The King v. Elliott, in 1905, the Ontario Court of Appeal declared that:

The right of competition is the right of every one, and Parliament has now shewn that its intention is to prevent oppressive and unreasonable restrictions upon the exercise of this right ....20

Seven years later, this emphasis appeared to be altered slightly by the Supreme Court of Canada in Weidman v. Shragge:

- the mischief aimed at is the undue and abusive lessening of competition which operates to the oppression of individuals or is injurious to the public generally. 21

Consistent with the theory of criminal conspiracy, deleterious effects have not been regarded as an essential element of the offence; and private injury soon came to be regarded as only one indicator of general public injury deriving from the fact of the agreement. No vicious purpose was required. This emphasis upon competition rather than upon competitors is evident from the Supreme Court decision in Howard Smith in 1957:

The public is entitled to the benefit of free competition, and the prohibitions of the Act cannot be evaded by good motives. ${ }^{22}$

In the Canadian Breweries case in 1960, Chief Justice McRuer in the Ontario High Court concluded that:

In the last analysis, the object of the Combines Act is to protect the public interest against the enhancement of prices that will likely flow from combines

19 An interesting contrast to the debates of 1888 and 1889 is the debate in 1877 , ante, $\mathrm{n}$. 13 , over the Breaches of Contracts Bill, which was enacted as (Can.) 1877, c. 35, and later became s. 521 of the Criminal Code. Certain pre-Confederation statutes had made bresches of contract criminal; and the Minister of Justice, Mr. Blake, contended that the views upon which those laws were founded were no longer held. The prevailing the views upon which those laws were founded were no longer held. The prevailing
philosophy as implemented in 1877 was that only those breaches that were maliclous, or philosophy as implemented in 1877 was that only those breaches that were maliclous, or
in relation to which the person had cause to belleve that the consequences would include such things as serious bodily injury, destruction of valuable property, danger to health, or would cause great public inconvenience, were properly the concern of the criminal law.

20 (1905), 9 C.C.C. 515, 520 (Osler, J.A.).

21 (1912), 46 S.C.R. 1, 4 (Fitzpatrick, C.J.). Duff and Anglin, JJ., also emphasized the significant commercial aspects of the case as being relevant to a determination of the criminality of the act; while Idington. J., at p. 20, showed greater concern for "the viclous purpose almed at" as a criterion of liability.

22 Howard Smith Paper Mills Limited v. The Queen (1957), 26 C.R. 1, 4 (Taschereau, J.). 
as defined in the Act. It matters not whether they arise out of agreements, mergers, trusts or monopolies.:::

A violation of this public right, then, is ostensibly similar to any other criminal offence in that there is detriment to the public as a whole, and often detriment to a particular individual. However, the public injury is not one of physical order, health, safety, or morals; but, rather, is a restriction upon the operation of an economic policy. It can be caused by an innocent and natural business decision.

The opinions of the enforcement agencies are also of critical importance on the question of public interest, since their views underlie any decisions to investigate, report, and prosecute. The Director of Investigation and Research has recently stated that:

The purpose of Canadian anti-combines legislation is to assist in maintaining free and open competition as a prime stimulus to the achievement of maximum production, distribution and employment in a system of free enterprise.24

It must be noted that, while the relevant interest is usually expressed as being "free competition," the statute strikes at only certain classes of restraints upon free competition. In this sense, the criteria remain private actions rather than public right. Nor must "free competition" be confused with "perfect competition," which has never been more than a utopian model for the exposition of economic theory. The Canadian legislation really goes to ensure what antitrust economists call "effective competition.":s Whereas "free competition" precludes any significant economic concentration and has definite political overtones, "effective competition" finds its meaning in economic terms and goals. The distinction is significant, because a strict view of free competition would entail prohibition of other price-forming forces possibly not proscribed by the Act. Examples include conscious parallelism and price leadership as

23 R. v. Canadian Breweries Ltd. (1960), 33 C.R. 1, 32. See also R. v. British Columbia Sugar Refining Company Limited (1960), 36 C.R. 32, 88, where "excessive or exorbitant profits or prices" were regarded as a requisite element of the offence. Both cases concerned mergers. In conspiracy cases the courts have professed inability Both cases concerned mergers. In conspiracy cases the courts have professed inability
to determine such issues. The ill-fated Board of Commerce Act, 1919, and The Combines and Fair Prices Act, 1919, were doomed constitutionally because they related directly to prices. It would appear that the main thrust of the present statute is to ensure that prices, inter alia, are controlled by the forces of effective competition and that this is to be the only test of their exorbitancy.

The Norwegian legislation states the control of price and profit levels to be one of its dominant concerns. Norway has had a long history of price control in its emphasis upon the economic goal of full employment rather than free competition. It is interesting to note that, to this end, the central adjudicative tribunal in Norway is an ad. ministrative body composed of lawyers, economists and businessmen qualifled by their expertlse in business, commerce, and public affairs: see Guide to Legislation on Restrictive Business Practices in Europe and North America, O.E.C.D., Vol. III.

24 Report of the Director of Investigation and Research for the year ended March 31, 1964, p. 7. This view of the philosophy underlying the Act conforms to a more extensive statement made by the Minister of Justice: see House of Commons Debates, 1960, p. 4344.

2.: A statement to this effect was made by the Chairman of the Restrictive Trade Practices Commission in 1960: see C. Rhodes Smith. "Canadian Policy Toward Combines," In Proceedings, International Conference on Control of Restrictive Business Practices, 63 (University of Chicago 1960). For a discussion of the concept of "effective" or "workable" competition, see the Report of the Attorney-General's National Committee to Study the Antitrust Laws, Ch. VII (Washington 1955). 
emblems of an oligopolistic industry structure. ${ }^{20}$ Nor has there been any indication that the Act will catch the increasingly common conglomerate merger which marks the current industrial trend to diversification.

In summary, the emphasis of combines law enforcement appears to have shifted from the protection of an atomized competition to the general performance of the economy. The latter concern, not yet clearly acknowledged at the judicial stage of the administration, isolates only those aspects of competitive rivalry which bear upon allocation of resources, use of capacity, and distribution. The point is that as the offence becomes less personal and less easily definable, the successful performance of the criminal remedy becomes compromised.

\section{Moral Values}

Concepts of moral responsibility and delinquency are an integral part of our criminal law. A criminal offence, as an injury to society and therefore to all its members, usually carries a social stigma. This opprobrium is inextricably related to attendant publicity and to the general belief that a criminal offence should be defined with such specificity that a person knows or ought to know when he is offending the norm of conduct set out by the law. It has been seen that moral considerations partially inspired the original combines legislation, but also that the emphasis of the various values involved has shifted toward a primary concern over the functioning of the national economy. To what extent do moral values remain significant in our combines laws?

Moral considerations in law are of two classes. An offence may be generally agreed to be intrinsically wrong and morally reprehensible. Examples include sex offences, fraud, and most types of murder. In 1889 Parliament regarded combines as being in this category. The other type involves breach of a statute, where the actor knows the law but acts in contravention of it anyway. Income tax evasion and breaches of specific regulations or orders come into this class. Can the combines laws today be placed in either of these categories?

As might be expected, the courts are less inclined to pass moral judgment upon corporations than upon individuals:

As the accused are all ... corporations, not much is to be gained by discussing questions of moral turpitude, for the persons whose morals would be the subject of discussion are not before the Court.27

20 This is not to suggest that these situations could never offend a concept of workable competition. The reach of the Act toward price leadership may be indicated if the recent inquiry into the pencil industry results in a prosecution. See $A$ Report in an Inquiry under the Combines Investigation Act Concerning the Manufacture, Distribution and Sale of Pencils, R.T.P.C. No. 31, p. 50 (Ottawa 1964).

For those unfamillar with the terminology, the following definitions are given by the Glossary of Terms Relating to Restrictive Business Practices (O.E.C.D., 1965): Consclous parallel action:

A partial or total uniformity or harmonisation of the market behavlour of enterprises, which is not the result of any explicit or implicit agreement. but of individual actions of these enterprises, each of which is aware of and confidently expects the corresponding acts of the others and might act otherwise but for these acts.

acts. leadership:

A form of consclous parallelism with regard to prices, whereby the price policy of one enterprise, the price leader, is deliberately followed by the others. Oligopoly:

The occupancy of a market, or a large part of a market, by a small number of enterprises, each of which possesses a significant degree of economic power which it exercises independently, but taking into account the market conduct of other enterprises.

27 R. v. Container Materials Ltd. (1941), 76 C.C.C. 18, 54 (Ont. C.A.), per Robertson, C.J.O. 
Yet, the ethical quality of business practices can be relevant to the issue of whether a merger or monopoly is likely to be operated to the detriment of the public. ${ }^{2 s}$ The early view held in respect of the conspiracy offence did make moral considerations revelant to the issue of liability:

This being a criminal statute we must try to find the vicious purpose aimed at in order to bring parties within its prohibitions. ${ }^{29}$

The relevance of mala fides exists, usually, in relation to prescribing sentence for individual offenders. It is bound up with the problem of the deterrent force of the criminal law. The effectiveness of sentence as a deterrent force is difficult to estimate, but it may be noted that an individual has yet to be incarcerated in Canada for a combines offence.

The courts have been, on occasion, quite offended by deliberate unethical conduct of individuals:

It is not easy to understand why businessmen, otherwise reputable and honest in their dealings, and whose commercial ethics would normally appear to be beyond question, could be so conscienceless as to embark in a manner so deliberate and premeditated upon such a far-reaching co-operative design to violate a law enacted to protect the public interest in free competition. ${ }^{30}$

It appears that individual deeds must be obviously and independently morally blameworthy before they become relevant to sentence. Since the offence is contained in such a vague proscription of conduct, this position is to be welcomed. The view of the Ontario Court of Appeal in Container Materials is well known:

... it would be a mistake for this Court to look upon the appellants as guilty of moral turpitude or of a wicked intention. Their directors are honourable men desirous of conducting successfully the affairs of their respective companies, and if in their efforts they have by mistake over-stepped the line set by Parliament and have unduly lessened competition they are responsible for their unlawful act ... Breach of the statute is one thing, moral turpitude is quite another.31

It will be appreciated that combines offences derive from the same motivating forces that are supposed to characterize competition and make it valuable. Those inducements include the search for greater sales, for higher profit, and for a competitive advantage in the market. The law attempts to draw a line, beyond which practices directed to these ends become abusive. The criminal law works best where the offence is specific and is generally agreed to be intrinsically wrong. The combines legislation lacks both the specificity and the moral basis necessary for the

28 R. v. Eddy Match Company Ltd. (1951), 13 C.R. 217, 279 (Que. S.C.).

20 Weidman v. Shragge (1912), 46 S.C.R. 1, 20, per Idington, J.

30 R. v. Firestone Tire and Rubber Company of Canada Ltd. (1953), 17 C. R. 401,407

(Ont. High Court). See also R. v. McGuire, (1906), 7 O.W.R. 225; R. v. Clarke (1908),

1 Alta. L. R. 358; R. v. McGavin Bakeries Ltd. (No. 6) (1951-52), 13 C.R. 63, 95-96.

31 Ante, n. 27, at 61, per Masten, J.A. This view was adopted in R. v. Howard Smith Paper Mills Ltd. (1954), 19 C.R. 242, even though the maximum penalty was imposed.

The view expressed in Container Materials might be compared with a statement by the Minister of Justice in 1960 in speaking to the amendments which now form section $32(2),(3),(4)$ and $(5)$ :

I think the assistance to business might help them to avoid falling into temptation, and assistance to business in resisting temptation is still here. The penalties they know about; they know how the courts have interpreted the Act: and we have made it clear, I suggest, that we will now [sic] allow them to commit sin but, rather, will give them assistance by outlining the paths down which they may walk without danger. Now that, I think, is not a bad principle to incorporate into legislation. After ali, the function of theology is in part to instruct men in what they may do and what they may not do and how to avoid falling into sin or into the occasions of sin. Something along those lines is what we have tried to do here.

Proceedings of the Senate Standing Committee on Banking and Commerce, on Bill C-58, August 4, 1960, p. 74. 
definition of the point at which something to be encouraged becomes something to be discouraged. ${ }^{32}$ It is not surprising that subjective factors play little role in the law of competition. The relevance of moral considerations is largely limited to behavioural practices going to the quality of competition, rather than to offences going to industry structure.

\section{The Criminal Sanction}

\section{(a) Penalties}

The criminal fine has always been the basic penalty provided by the Act and utilized by the courts. The alternative of imprisonment of an individual has always existed; but, while judges have at times referred to this as a desirable penalty for some situations, ${ }^{33}$ it has yet to be requested by the Crown or imposed by the courts for a combines offence. It is widely believed that incarceration would have a substantial deterrent effect if it were made a real threat. The desirability of such an effect is another question.

The original limits of a fine of four thousand dollars upon an individual, or ten thousand dollars upon a corporation obtained until 1952 for the conspiracy offence. The fine for the old "combine" offence had been a maximum of ten thousand dollars for an individual and twentyfive thousand for a corporation since 1923. In 1952, in response to strong dissatisfaction with the low limits of permissible fines expressed by the judiciary, ${ }^{34}$ fines for both types of offences were made discretionary, to be set arbitrarily by the court. ${ }^{35}$ However, the cases involving imposition of the discretionary fine have so far been few. This has come about largely because the penalty is not regarded as having been mitigated by the change, so that, if the period of the conspiracy alleged began prior to 1952, the court is limited by the old provisions for fines. ${ }^{30}$

R. v. Abitibi Power and Paper Company is one of the few cases involving imposition of the discretionary fine. ${ }^{97} \mathrm{Mr}$. Justice Batshaw there indicated an emphasis upon the total fine, to be apportioned among the various accused corporations:

... the accused in this case should be sentenced to pay fines in the total sum of

$\$ 240,000.00$, which I hereby impose and apportion ... as follows ...38

It is worthy of notice that the highest single fine levied in the case was twenty-five thousand dollars, which is equal to the previous statutory limit under the Combines Investigation Act, 1923. On the other hand, Abitibi was a conspiracy case. A similar emphasis upon the total of all fines was indicated in the sentencing of five metal culvert companies in

82 These same problems of "moral neutrality" and inability to achleve specificity have been dlagnosed in other related areas of law: see Kadish, Some Observations on the Use of Criminal Sanctions in Enforcing Economic Regulations (1963), 30 U. of Chicago L. Rev. 423.

ss See, for example, the McGavin Bakeries case, ante, n. 30.

34 See R. v. Firestone Tire and Rubber Company of Canada Ltd. (1953), 17 C.R. 401, 408; and Howard Smith, ante, n. 31 at 244. There was no moral condemnation in the latter case.

35 The House of Commons Debates for 1951 (2nd sess.) and 1952 indicate that the prime motivating forces behind the discretionary fine were an inarticulate compensatory principle and deterrence.

30 R. v. Crown Zellerbach Canada Limited (1957), 25 C.R. 217 (B.C.C.A.), per Coady, J.A. 37 (1960), 36 C.R. 96 (Que. S.C.).

3. Id. at 156. 
$1959^{39}$. It is submitted that such emphasis is only proper in cases involving intra-enterprise conspiracy (e.g. Eddy $M_{a t c h}{ }^{40}$ ).

Incarceration of the offender is a serious step, especially where the proscribed conduct cannot be articulated with reasonable specificity. Nor is the fine an ideal penalty for an individual. Its chief merit is the ease with which it may be enforced; but there is no way, short of an unlikely action by the shareholders, of preventing voluntary indemnification by the corporation.

The only other formal remedy presently utilized is a prohibition order, which was made possible by the 1952 amendments."1 Section 31 (1) provides for such an order attendant upon a prosecution and a conviction, and section 31 (2) provides for the order for incipient offences without a criminal conviction. Needless to say, interesting constitutional law problems are raised, but it is beyond the purview of this paper to deal with them in any detail. Several orders have been issued upon conviction under section $31(1)$. The leading case on the principles and form of this penalty is $R$. v. Goodyear Tire and Rubber Co. ${ }^{42}$ The criteria used to determine the propriety of the order appear to be the duration of the crime, the scope of the criminal arrangement and the degree of control achieved by the arrangement. ${ }^{13}$ It might well be argued that these criteria improperly emphasize past behaviour rather than future conduct. The prohibition order, at least under section $31(1)$, has been constitutionally justified as criminal law in that it goes to the prevention of crime.

A convicted party can tender evidence that the condemned conduct has been discontinued, and that there is no need for the order; but the indications are that if the Crown calls for the order it will be granted unless the accused objects.

The power given to the court by section 31 (1) is very broad indeed, despite the apparent limitation that it be used as a penalty upon conviction. The courts have expressed misgivings about the implications of any specificity in the proscribed activities:

I have some doubts about my right to specify various individual acts in the order .... I do not see how I can predetermine some of these acts by setting them out in the order.44

The obvious problem is that in the field of combines, most acts depend upon their economic context for their criminal quality.

The orders have been, however, both general and particular, and several contain clauses possessing each quality. It has been held that the order may extend to any person who stands in such a relation to the accused that a prohibition upon him would act as a penalty upon the accused. ${ }^{45}$ Justification of this as a criminal penalty requires rather tenuous reasoning. The order would appear more to approximate regulation by injunction than a sanction for a criminal offence. Obviously,

\footnotetext{
80 Recorded in the Report of the Director of Investigation and Research for the year ended March 31, 1960, p. 13.

10 Ante, n. 28.

41 (Can.) 1952, c. 39, s. 3.

12 See the judgment of the Ontario Court of Apeal in (1954), 18 C.R. 245 affd. [1956] S.C.R. 303.

13 Goodyear, as interpreted and applied in $R$. v. Dominion Steel and Coal Corp. Ltd. (1957), 116 C.C.C. 117, 138-39 (Ont. High Court)

14 R. v. Dominion Steel and Coal Corp. Ltd., id. at 139.

45 See Goodyear, ante, n. 42; and $R$. v. Electrical Contractors Association of Ontario and Dent (1960), 127 C.C.C. 273 (Ont. High Court). Note also the opposite inclinations in the Howard Smith case (1954), 19 C.R. 242, 252.
} 
a general prohibition order is little better than the statute itself; while a particular order, even assuming assiduous supervision by the Combines Branch, suffers the limitations of language in directing precisely what the offender must not do. No enforcement actions have yet reached the courts.

Orders granted under section 31 (2) without a conviction display even greater potential as a regulatory device. It is worthy of note that, of the four cases in which these orders have been granted, not one was defended. And yet, of all sections in the statute, this is the one resting on the most insecure constitutional grounds.

Despite any tendency for these prohibition orders to perform a regulatory function, such a use is partially frustrated by the criminal aspect, which requires prohibitions rather than openly positive direction.

Until the new Criminal Code came into effect in 1955, costs could also be awarded as a form of combines penalty, and the practice was to do so in cases where special circumstances were demonstrated. Such special circumstances might be acts of subterfuge and concealment. Costs can no longer be awarded; but, while the courts have suggested that this is unfortunate, the discretionary fine surely gives full scope for any financial detriment to be inflicted by way of punishment.

\section{(b) Liability of Individuals}

The combines law has always contained separate provision for the sentencing of individuals; and, while no individual in Canada has ever been sent to jail for a combines offence, officers and independent entrepreneurs have occasionally been fined. ${ }^{43}$ Incarceration for default of payment is invariably prescribed, but only as a normal procedure for guaranteeing payment of a pecuniary penalty. Usually an individual will only be prosecuted if he has been particularly active in engineering the conspiracy ${ }^{47}$ or has carried out deeds of low moral or ethical principle. ${ }^{48}$ Individuals conspiring through an unincorporated association will also be charged. ${ }^{40}$

However, R. v. Singer; R. v. Belyea and Weinraub ${ }^{50}$ points up that the degree of participation does not go to liability but is at best only a factor

16 From 1950 until September 20, 1962, 211 fines were levied for substantive offences under the combines legislation. Of these, 23 were levied on individual persons. Only one of the twenty-three came under the discretionary fine provisions, and that accused was finded $\$ 7,500.00$. For the other twenty-two the statutory ceiling of $\$ 4,000.00$ obtained. finded $\$ 7,500.00$. For the other twenty-two the statutory ceiling of $\$ 4,000.00$ obtained.
Two were fined this maximum, and the remaining twenty fines were below $\$ 1,800.00$. (Statistics complled from tables in House of Commons Debates, 1960, pp. 855-58, and 1962-63, pp. 507-08.).

17 See, e.g. The King v. Elliott (1905), 9 C.C.C. 505; The King v. McMichael (1907), 18 C.C.C. 185; and $R$. v. Electrical Contractors Association of Ontario (1961), 131 C.C.C. 145

18 See Rex v. McGuire (1906), 7 O.W.R. 225; and Rex v. Clarke (1908), 1 Alta. L.R. 358. Yet, see R. v. McGavin Bakeries Ltd. (No. 6) (1951), 13 C.R. 63, 95, where the trial judge declared:

In only two of all the Canadian cases against combines can $I$ find the officers of the corporations expressly relieved of moral responsibility or, as it is called in those cases, moral turpltude .

There has periodically existed concern in Canada over the number of executives of American subsidiaries in Canada who are American citizens rather than Canadian. What are the implications, if any, of the Immigration Act, R.S.C. 1952, c. 325, s. 5(d)? That are the implications, If any, of the Immigration Act, R.S.C. 1952, c. 325, S. 5(d)? That
section bars entry into Canada and is consequently ground for a deportation order, for:
persons who have been convicted of or admit having committed any crime involving moral turpitude.

The Governor in Council can waive this ban, essentially on the basis that the party has "rehabllitated himself "

19 See $R$. v. Alexander Ltd. (1932), 57 C.C.C. 346. See also R. v. Adams Coal Co. (1957), 27 C.R. 47, where individual entrepreneurs conspired with corporations on an equal footing.

so (1931), 56 C.C.C. $68 ;(1931), 56$ C.C.C. 87 (Ont. C.A.); Belyea v. The King [1932] S.C.R. 279. 
influencing the Crown's decision to prosecute. It may also go to sentence. The Ontario Court of Appeal reversed an acquittal of Belyea and Wienraub at trial on the basis that the offence consisted in the fact of conspiracy and not in the overt acts done in furtherance of the crime.

The law appears unclear in settling the point at which the corporate veil may be disregarded and the officer found guilty of conspiracy with the company. Obiter dicta in the Electrical Contractors case ${ }^{31}$ indicates this possibility even where the officer acts in a solely representative capacity, but the ratio of that case extends only to the situation where the officer acts in more than one capacity. ${ }^{52}$ Even this latter reasoning can render many officers liable if carried far enough. As a practical point, however, the Crown is only likely to charge individuals if they played a distinctive role in the offence.

Incarceration as a penalty for the combines offender has been mentioned only infrequently in Canadian courts. It has received more strenuous and consistent support from various Members of Parliament. There are obvious problems in the use of this penalty. If it is to serve as a deterrent, it ought only to be utilized where the proscribed conduct can be articulated with reasonable specificity. There are more effective ways to protect society, if this is to be regarded as the object of the sentence. Also, it would be little short of ludicrous to suggest that our present prison system could "rehabilitate" these pillars of society.

There is much to be said for aiming at those persons who make corporate decisions, but the weapon with which to aim is none too clear. The shortcomings of the fine have been mentioned already. A tendency to use incarceration for certain offences has been demonstrated recently in the United States. ${ }^{.3}$

\section{(c) Sentencing}

A survey of the cases indicates a wide range of factors which have been considered relevant to sentence. It will be more graphic, if also more arbitrary, to list these in order of apparent significance as they appear from the judgments. The factors as listed presume liability. The following go to the general gravity of the offence of which all are guilty:

(1) extent of control in the industry, ${ }^{54}$

(2) duration of the offence,, 53

(3) magnitude of the aggregate business involved,56

(4) deliberate fraud and misrepresentation,, 57

(5) commercial and social significance of the relevant commodity, ${ }^{38}$ and

(6) financial loss to the public.50

51 Ante, n. 47, at 152.

52 The United States courts have adopted the position taken in the obiter. See U.S. v. Wise (1962), 370 U.S. 405.

53 For a good discussion of the problems of individual liability and sanctions in the specific context of the notorious electrical conspiracy, see the note in 71 Yale L.J. 280; and see Watkins, Electrical Equipment Antitrust Cases-Their Implications for Government and for Business (1961), 29. U. of Chicago L. Rev, 97. Note also U.S. v. McDonough ment and for Business (1961), 29. U. of Chicago L. Rev, 97. Note also U.S. V. McDonough
Co., [1959] Trade Cases 69, 482 (Dist. Ct.), where for the first time incarceration was part of the penalty on an accepted plea of nolo contendere. Four corporate officers were there sentenced to ninety days in jail, as well as to fines. (Incidentally, one of of the officers committed suicide prior to serving his sentence).

54 See R. v. Goodyear Tire and Rubber Co. (1953), 17 C.R. 252; R. v. Dominion Rubber Co. (1953), i7 C.R. 409; R. v. Firestone Tire and Rubber Co. of Canada Ltd. (1953), 17 C.R. 401; R. v. Dominion Steel and Conl Corp. Ltd. (1957), 116 C.C.C. 117, 136; R. v. Abitibi Power and Paper Co. (1960), 36 C.R. 96, 155-56.

55 See the Goodyear and Dominion Steel cases, ibid.

so E.8., the Firestone case, ante, n. 54.

57 R. v. Central Supply Assoc. Limited (1907), 12 C.C.C. 371, 381-82; R. v. Singer; $R$. v. Belyea (1981), 56 C.C.C. 68, 84; McGavin, ante, n. 48; Goodyear, ante, n. 54; and Dominion Rubber ante, n. 54

59 The King v. Elliott (1905), 9 C.C.C. 505, 510-11; McGavin, ante, n. 48.

.0 McGavin, ante, n. 48 . 
These categories contain, of necessity, a certain degree of overlap. It will be noted that all but the fourth relate to the commercial significance of the arrangement upon the economy as a whole. In this, they relate to the effects of the crime, rather than to the conspiracy itself.

There are other areas of the criminal law which demonstrate similar attention to the result of the crime as a sentencing factor. To an extent, such an approach may be thought necessary to satisfy vestiges in the mind of the public of a retribution philosophy of punishment; but recent concern over sentencing problems is turning the emphasis toward the offender and away from the offence. This is in keeping with a reassessment of the purpose of the criminal sanction. Public clamour over sentence disparities stems from looking only to the effects of the particular crime, whereas more tools have become usuable for evaluating the nature of the problem presented by each criminal offence and offender. The present tendency of the criminal process is to take more cognizance of sentencing objectives and responsibilities.

It may be argued that the combines problem is totally unreceptive to this type of approach. The natural suspicion is that problems in this area are only other manifestations of an improper placement of combines within the ambit of criminal law. However, given that it is to remain within the criminal law, the necessary sentencing tools must be developed. An example would be the report of the Restrictive Trade Practices Commission, which ideally contains some economic evaluation of the impact of the arrangement upon the public interest as well as a discussion of the economic forces present upon the parties. The report might well be made admissible for purposes of sentence.

There are a few additional considerations of a personal nature which apply only to sentences of individuals. ${ }^{60}$ Other factors concern the relative criminality of the various offenders and go to penalty differentials between parties to the same offence. These include degrees of participation and initiative, ${ }^{, 1}$ gross annual sales of each participant, ${ }^{62}$ and suppression of evidence. ${ }^{63}$

Elements of coercion which can and do occur have definite similiarties to physical duress. In The King v. Elliott:

... there was intimidation of a character likely to be quite as effectual as, if not more so than, even a threat of physical force .... iti

There can be no doubt that despite the element of coercion, which can go to the life and viability of a commercial entity, such a consideration does not affect the issue of liability. This position is consistent with traditional criminal theory. Section 366 of the Criminal Code makes intimidation a summary offence, but not an excuse for the intimidated party. In practice, the fact of duress is taken into account, if at all, by

60 The clearest cases are Rex. v. McGuire (1906), 7 O.W.R. 225, 229-30; R. v. Alexander Ltd. (1954), 19 C.R. 242, 248; Abitibi, ante, n. 54, at 155-56.

61 Singer, ante, n. 57, at 85; $R$. v. Canadian Import Co. (1933), 61 C.C.C. 114. 167; R. v. Container Materials Ltd. (1940). 74 C.C.C. 113, 153; $R$. v. Howard Smith Paper Mills Ltd. (1954), 19 C.R. 242, 248; Abitibi, ante, n. 54, at 155-56.

62 Howord Smith, id., at 247; R. v. Adams Coal Co. (1957), 27 C.R. 47, 57. The court will not impose such a heavy fine as will endanger the existence of the company: see $R$. v. Link-Belt Limited (Ontario High Court-unreported, 1957).

63 See, e.g. Firestone, ante, n. 54.

61 (1905), 9 C.C.C. 505, 510. 
the Crown in its selection of the parties to prosecute. ${ }^{65}$ One would expect such a consideration to go to sentence if the Crown decided to prosecute, but at this level the elements of duress become confused with several other often-inarticulate criteria, and its effect alone is difficult to discover. The clearest statement available would indicate that duress has no bearing on the sentence. ${ }^{.6}$

There do not appear to be any sentencing factors peculiar to corporate offenders. Regardless of the revelance corporate reorganization may have to issues of liability, it appears to be irrelevant to sentence once liability is established. ${ }^{67}$ The same applies in cases of intra-enterprise conspiracy, although practical corollaries of this might lead to differentials based on other criteria. ${ }^{68}$

Whenever courts have had occasion to refer to a general sentencing philosophy in combines cases, they appear to base it upon deterrence. As enunciated in the Alexander case,

The penalties ought not to be vindictive, but they should be substantial, and under all the circumstances, particularly in view of the prosecution of the Master Plumbers in 1905, and the result of that prosecution, they ought to be exemplary. ${ }^{69}$

These sentiments, echoed in Canadian Import ${ }^{70}$ and Abitibi, ${ }^{71}$ indicate that generally deterrence, rather than retribution, ought to be the guide; but where decided cases lend such an element of certainty to the illegal character of the pursued conduct, then the sentence may properly be punitive.

The deterrent philosophy of sentencing presumably depends upon a party's ability to know with some degree of precision the point at which he contravenes the law. And, yet, once the court feels there is any element of certainty in a combines case, the sentence "ought to be exemplary." The statement in Alexander appears to involve some confusion. Additionally, we must consider that the combines laws have necessarily to be vague and capable of adaptation to a changing commercial context. Consequently, the subjective views of the administration and the judge may well be critical to the result. It seems harsh to think that the accused in Alexander should have felt strictly limited by the facts of Master Plumbers when a world war, the boom of the twenties, and the onset of the depression had intervened. The doctrine of stare decisis has disadvantages enough in the dynamics of commercial development, but surely it does not extend to findings of fact. "Undueness" is regarded by the courts as a question of fact, ${ }^{72}$ for no per se

65 A typical example is the McGavin Bakeries case, ante, $\mathrm{n}$. 48, at 80 , where it is reported that the accused companies "coaxed, cajoled and coerced" the small independents to toe the line, but the latter were not indicted.

68 R. v. Dominion Steel and Coal Corp Ltd. (1957), 116 C.C.C. 117, 136-37.

G7 R. v. Canadian Import Co. (1933), 61 C.C.C., 114, 168. In this connection, see also Adams Coal, ante, $n$. 62, where one corporate conspirator had ceased to exist by the time charges were laid, and so escaped indictment.

68 $R$. Vontainer Materials Ltd. (1940), 74 C.C.C. 113; R. v. Eddy Match Company Ltd. (195i), 13 C.R. 217; R. v. Howard Smith Paper Mills Ltd. (1954), 19 C.R. 1. In McGavin Bakeries, ante, $n$. 48, the three subsidiaries received the minimum penalty and the other three accused received near-maximum penalties.

60 (1932), 57 C.C.C. 346, 360

70 (1933), 61 C.C.C. 114,168

71 (1962), 36 C.R. 96, 155-56.

72 The King v. Elliott (1905), 9 C.C.C. 515, 520; R. v. McGavin Bakeries Ltd. (No. 6), (1951), 13 C.R. 63, 74; R. v. Abitibi Power and Paper Co. (1960), 36 C.R. 96, 149-50. There used to be confusion on this point; and in The King v. Gage (No. 2) (1907) 13 C.C.C. 428 , the matter went on appeal as a question of law, or at least as mixed fact and law. 
rule obtains in Canada. As a matter of law, only agreements which are "undue" are proscribed.

The criminal penalty traditionally aims at achieving positive results by negative means. If the main objectives of the criminal sanction may be meaningfully separated for discussion purposes, they include deterrence, protection of the public, "rehabilitation" of the offender, and an education of the public to the revelant norms of conduct such as may be deemed desirable. They derive from a very personalized level of concern; and the combines cases understandably demonstrate confusion and frustration in the attempts to adapt such a penalty to predominantly corporate offenders, where the evil relates to the health and structure of an economy.

The philosophy of deterrence, dominant in combines cases, is based upon normal Pavlovian reactions. The various elements of the criminal combines sanction include the cost of the trial, the penalty in open court with attendant publicity, and public repudiation. If the main force in combines cases is financial, the present penalties can only be regarded as totally inadequate. Regardless of the new discretionary fine, it has been seen that the courts are yet inclined to stay within the old statutory limits. ${ }^{i 3}$ Frequently, the conspiracies alleged have functioned over ten and fifteen year periods, and it is not surprising if the business community generally views combines trouble as just one of the costs of doing business. Also, of course, deterrence by financial deprivation is not peculiar to the criminal process.

An analysis of the effect of any opprobrium that may accompany a conviction must bear in mind that the only name and reputation a corporation possesses are measured actuarially. An artificial person can be seen neither in open court nor on the street. Its only friends are the parties it contracts with in business; and most often, if and when it is convicted, the only realistic business alternatives to which its customers could turn are companies which are also convicted. This is because the restriction had to be "undue." Consequently, if an analysis could be made which would isolate the criminal factor, a depreciation in goodwill would be surprising, and in a real sense would contradict the very correctness of the conviction.

In 1951, the Commissioner of Combines spoke favourably, if uneasily, of the deterrent value in combines administration:

The possibility of repeated offences, even after conviction, is one which cannot be dismissed lightly. No special provision is made in the Canadian Act for continued review of the practices so involved, but such re-examination that there has been suggests that practices condemned are not repeated by the offending companies. Firms once in trouble naturally prefer to avoid further entanglements with the law, and even the refusal of one or two to participate might well make it impossible for the group to carry on with any effective restrictive agreements. On some, of course, the effect may be to teach wariness in the keeping of incriminating records rather than care in the observance of the law. In any event there is a responsibility on the government agency to keep itself informed about the practices of firms whose joint activities have been the subject of previous investigation. ${ }^{7 \cdot}$

7: R. v. Adams Coal Co. (1957), 27 C.R., 47, demonstrates a tendency, on purported authority, to continue using the old statutory limits as a basis of comparison in order to set the amount of the fine.

i4 F. A. MeGregor, "Preventing Monopoly-Canadian Techniques" (1951), in Monopoly and Competition and Their Regulation, 359, 378 (ed. E. H. Chamberlin 1954). 
Following the recommendation of the MacQuarrie Report that machinery for the essential follow-up studies be established, ${ }^{75}$ section $31 \mathrm{~A}$ was placed in the Act and permits the court for a period of three years following a conviction to require a return of information concerning activities since conviction. This section has remained unused, with the supervisory effort of the Combines Branch resting largely upon newspaper clippings and trade journals.

If it be alleged that the real control of combines is carried out on a de facto regulatory basis at the administration level, this control is probably made possible by some deterrent force in the present law. It would be unrealistic, however, to attribute this force to the fact of the criminal process alone. Such considerations as disclosure of business details and the mere presence of government with all its powers would logically inspire co-operation.

There is no compensatory principle evident in the cases. This absence results from the realization by the courts that even with extensive economic analysis of price levels and a host of other data, it would be impossible to visualize the financial situation that would have obtained had the condemned arrangement not existed.

\section{(d) Role of Publicity}

The criminal law depends partially for its effectiveness upon a public awareness of the commission of the offence, and upon a collective repudiation of the conduct. This repudiation derives from the stigma traditionally attaching to criminal conduct, and is a necessary part of the educative function of the criminal process.

The role of publicity in combines is peculiar, however; and allusion has already been made to some of the reasons. The philosophy underlying the publication of the administration reports, which do not decide criminal responsibility yet may suggest it, was set out by Mr. Mackenzie King, as Minister of Labour, in 1910:

There are certain classes of evils in the remedying of which it is believed publicity is more effective than penalty. It may not be that publicity will in all cases prove an effective remedy, but certainly in industrial matters it has many times in the past proven to be effective. ${ }^{76}$

This statement recognizes publicity as an extra-judicial remedy for situations which may not be illegal in any way. The controversy over the publication of the Flour-Milling Report in 1949 bears dramatic testimony to the force believed to be inherent in this publicity. ${ }^{77}$ The reporting function was regarded as so important that in 1952 it was placed in the hands of a separate commission. Publicity as an informal type of sanction, its use hinged on the opinion of non-judicial agencies, may well be the most significant combines remedy.

The main publicity results from a report by the Restrictive Trade Practices Commission. The mere existence of such a report means, inter alia, that the Director of Investigation and Research believes the facts disclose a criminal offence. In a few cases the Commission has dis-

75 Report of the Committee to Study Combines Legislation, 41 (Ottawa 1952).

7 House of Commons Debates, 1909-10, p. 2059.

77 Investigation into an Alleged Combine in the Manufacture, Distribution and Sale of Flour and other Grain-Mill Products, (Ottawa 1948). The main outcry protesting the original decision not to publish is found at scattered locations throughout House of Commons Debates, 1949 (and session). 
agreed with the Director, and has recommended that no remedy be applied. However, by far the majority of reports are unfavourable. Few on either side would dispute that the opprobrium of the criminal law attaches to such a report.

Inquiry by the government is essential, and the Combines Branch cannot be reticent in its investigations. However, firms ought not to be penalized for this. The revelant "public" for an industry might well be limited to wholesale or retail companies which deal with it, and to provincial governments which give it large contracts. ${ }^{i 8}$ One is spurred to speculation about a de facto regulatory approach to Canadian combines administration and enforcement. It is not surprising that, in planning their activities, businessmen show at least as much concern for the Director's interpretation of the law as they do for the interpretation of the courts as contained in the reported cases.

The whole principle of publicity in the criminal process hinges upon a conviction in open court, after a trial in which all the usual rules of criminal procedure are followed. The function of publicity in combines is inconsistent with these basic principles; and, indeed, has been defended partially on the basis of the problems created by treating it strictly as an instrument of the criminal process:

Should [the report] not be limited to the facts brought out as evidence at the trial? If some pleaded guilty and others did not, or if all pleaded guilty on one charge and other charges were dropped, would the report have to be restricted to the guilty and to the counts on which they had been convicted? Would the report have to be limited in its description and findings to the persons actually condemned at the trial? If acquittals were secured on technical grounds, should the report be withheld entirely? If only companies were convicted would the report have to omit reference, by name, to officials of the companies who were coconspirators but who ordinarily are not prosecuted? Would it have to omit reference to a corporation which, by company reorganization and surrender of charter, had technically disappeared? Would reference to non-Canadian companies have to be omitted? ... In the end, to avoid the difficulties caused by delayed publication, the report would probably have to be rewritten, if not scrapped. ${ }^{70}$

This latter conclusion may well be the correct one if combines enforcement is to remain a concern of the criminal law. Many of the present difficulties could be avoided if the Commission concerned itself more with an economic evaluation, than with offering a determination of the legal issues, of the fact situation before it.

\section{COMBINES AND THE CRIMINAL PROCESS}

The various rules that characterize the criminal process manifest a concern to safeguard the liberty and character of each individual from inaccurate or improper allegation or force. Involving as it does fundamental political values, the criminal process requires society to meet very stringent requirements indeed, in order to demonstrate that the liberty of an accused is so harmful to social order that its deprivation, or some other penalty imposed by the collective body, is in the public interest. The principles stem from the nature of the remedy, and they condition the entire enforcement process.

78 Following publication of the recent report on road surfacing in Ontario, the Ontario government announced that for three months none of the firms implicated would receive zovernment contracts.

in McGregor, ante, $n$. 74, at 373. It is not material that this statement related specifically to the machinery which was discarded in 1952. 
In the B.C. Sugar merger case, Chief Justice Williams of the Manitoba Court of Queen's Bench explained the basic character of the trial:

As this is a criminal prosecution there are certain principles that I must apply to its consideration. They are: (1) The onus is on the Crown throughout to prove its case and every essential part of it by relevant and admissible evidence beyond a reasonable doubt; (2) This onus never shifts; (3) There is no onus on the accused to prove their innocence; (4) To the extent that the guilt of the accused depends on circumstantial evidence, that evidence must be consistent with the guilt of the accused and inconsistent with any other rational conclusion; (5) In the construction of a penal statute, such as the Combines Act, if there are two or more reasonable interpretations possible, the interpretation most favourable to the accused must be adopted."vo

Are these principles really appropriate for the control of competition? Have the courts regarded them as appropriate?

\section{Burden of Proof}

The principles enunciated in B.C. Sugar have been present in the minds or on the tongues of the courts in the majority of combines cases. Yet, the object of proof for which the principles originated was a concrete fact, such as whether A knew what has was doing when he killed B, or whether $X$ did in fact abscond with the missing money. Obvious problems arise in the attempt to apply these principles to an inquiry as to whether or not there was a conspiracy to limit competition "unduly," or whether or not competition "is or is likely to be lessened to the detriment or against the interest of the public." It would seem that the criminal principles must either be overthrown or be severely compromised if any convictions are to be obtained under the Combines Investigation Act. Section 32 (1) (b) has highlighted the economic problems of fact in the statute, making criminal an agreement "to enhance unreasonably the price [of an article]." The courts appreciate the difficulty of any attempt to prove such a proposition:

To put on the Crown the proof of what influences buyers to buy is a burden that has not yet been imposed by jurisprudence. ${ }^{\times 1}$

It is trite to say that crimes of conspiracy can rarely be proven by direct evidence, and the court almost invariably must rely upon cirsumstantial evidence from which the agreement charged may be inferred. An established principle of criminal justice, first articulated by Baron Alderson in his charge to the jury in Hodge's Case, becomes relevant:

$\ldots$ the case was made up of circumstances entirely; and that, before they could find the prisoner guilty, they must be satisfied not only that those circumstances were consistent with his having committed the act, but they must also be satisfied that the facts were such as to be inconsistent with any other rational conclusion than that the prisoner was the guilty person." [Italicized in the original.]

Canadian combines cases regularly pay lip-service to this rule for the use of circumstantial evidence; ${ }^{* 3}$ but it is apparent that the normal operation of the rule is emasculated by the presumption, in combines, from the basic fact of an undue effect upon competition to a presumed fact that the accused intended to act in combination to restrict competition unduly. This problem will be treated shortly in relation to the concept of intent in the combines offence.

so R. v. British Columbia Sugar Refining Company Limited (1960), 36 C.R. 32, 51.

${ }_{1} \boldsymbol{R}$. v. Northern Electric Co. (1955), 21 C.R. 45, 57.

*2 (1838), 2 Lewin's C.C. 227, 228.

83 E.g. R. v. McGavin Bakeries Ltd. (No. 6) (1951), 13 C.R. 63, 76-77; Northern Electric, ante, n. 81 , at 48 . 
Hodge's Case involved a charge of murder. It is interesting to compare the circumstantial evidence rule as there enunciated with its purported application in Abitibi, where several paper companies were charged with conspiring to prevent or lessen unduly the competition in pulpwood:

. . the proof points much more consistently, logically and reasonably to the inference of a single agreement rather than to a series of arrangements which might reasonably be regarded as separate, distinct and multiple ones. ${ }^{84}$

A proper application of the circumstantial evidence rule would have involved a closer examination of the inconsistencies than of the consistencies. Also, the word "reasonably" as used above does not accurately represent the criminal standard of proof beyond a reasonable doubt.

The key issues of fact in combines cases are essentially economic questions. The evidence is usually in the form of thousands of pages of business documents. It is beyond the scope of this essay to treat fully the wide variety of evidentiary problems raised by the attempted application of traditional rules of criminal evidence. They include the admissibility of records which would demand auditor's training for their intelligent use by the court, the conditional admittance of evidence at a point in the trial when its relevance is not yet appreciated, admission of evidence against one conspirator to go to his co-conspirators once common design is shown, problems of corroboration of the evidence of co-conspirators, and questions of the purposes for which inter-office memoranda may be admitted.

Section 41 is the major evidentiary provision of the Combines Investigation Act. Placed in the statute in 1949 to surmount problems attending the use of papers obviously relating to the business of a corporation as evidence against the corporation, the section operates to compromise the rigorous standard of proof required to establish criminal guilt. $^{\text {s. }}$ By the section, any document found on the premises or in the possession of any accused or a conspirator or their agents, is admissible as evidence of the truth of the facts claimed or alleged in the document. ${ }^{86}$ Knowlege of the contents is presumed. The central phrase prescribing the effect of the section is "shall prima facie be deemed." This presumption is most extensive in a criminal statute, because it offsets the higher standard of proof required for criminal guilt.

The first court to consider section 41 described its effect as follows:

It has not deprived the accused of any means of defence but has, on the other hand, relieved the prosecution of the ordinary proof that must be made in criminal matters. ${ }^{87}$

The general rule is that adjectival law will be applied retrospectively, whereas substantive rules will not. Dicey has classified evidence as procedural; but the courts, understandably, have had some difficulty in holding that section 41 falls into this category. The impact of the section

84 R. v. Abitibi Power and Paper Co. (1960), 36 C.R. 96, 133. See also p. 120 for treatment of evidence that, in fact, several purchases were made at prices higher than those allegedly set by the conspiracy.

85 The immediate inspiration of the section was the frustrating acquittal by directed verdict in R. v. Ash-Temple Ltd., |1949| O.R. 315. See a comment on this case by H. C. Goldenberg at (1949), 27 Can. B. Rev. 462, where it is suggested that the root of the problem is that the Combines Investigation Act is "modern economic legislation."

86 The section appears to distinguish between documents "in the possession" and those "on premises"; and, given this, documents proved only to have been on the premises of an agent of a participant do not appear to come within the section.

87 R. v. Eddy Match Company Ltd. (1951), 13 C.R. 217, 291 (Que. K.B.). This statement was approved by Mr. Justice Cartwright in R. v. Howard Smith Paper Mills Ltd., [1957] S.C.R. 403. 
upon the disposition of a case, and consequently upon the substantive rights involved, has been extraordinary for a mere procedural rule. While the courts have been reticent in their policy criticisms, they do incline to a strict construction of the section. ${ }^{88}$

It is academic to debate whether section 41 operates to assist the Crown in the discharge of its usual burden, or whether it goes to the very nature of the burden. The point is that the section operates to diminish the practical problems of proof which the Crown would otherwise face, and in some cases means that the mere introduction of the evidence is enough to satisfy the full burden of the Crown. It is also apparent that, once a co-conspirator is involved by the doctrine of common design, evidence against him will come from the premises of all accused parties so implicated.

The common law position was that, apart from insanity, the accused was not obliged to prove any defences in a criminal trial. Aside from any potential in section 41, the Combines Investigation Act has few specific derogations from this principle. Several defences were added to conspiracy charges in 1960 , which presently are found in sections 32 (2) and (3). The distribution of the onus, and the quantum of proof required in relation to these defences, has not yet become clear; although section 32 (2) vaguely resembles the English "gateways" legislation in this field, under which legislation the onus is upon the businessman. ${ }^{89}$ It is also possible that an accused on a charge of refusing to sell or to supply, bears the onus of proving justification once the fact of refusal has been demonstrated by the Crown. ${ }^{90}$

\section{Reasonable Doubt}

Given that realistic appraisals of "undueness" and detriment to the interest of the public necessarily go to economic factors, it may well be asked how any significant number of cases could meet the criminal standard of proof beyond all reasonable doubt. By that standard, the accused is to have the benefit of any reasonable doubt concerning findings of fact.

The importance of the reasonable doubt principle to the criminal law cannot be overstated. Although some combines cases have resulted in acquittals on the purported basis that the standard had not been met, ${ }^{01}$ and several other cases have yielded findings specifically to the contrary and convictions, ${ }^{02}$ there has been no serious treatment or discussion of the function of this principle in combines cases. It is of no real assistance to analyze the facts of cases and to substitute one's own judgment for that of the court. The question remains whether, regardless of the quality of

88 See R. v. Eddy Match Company Ltd. (1951), 13 C.R. 217, 295; Eddy Match Co. v. The Queen (1953), 18 C.R. 357, 367; R. v. McGavin Bakeries Ltd. (No. 5) (1951), 2 W.W.R. (N.S.) 305; R. v. Howard Smith Paper Mills Ltd. (1954), 19 C.R. 1; B.C. Sugar, ante, n. 80 , at 85 .

80 The Restrictive Trade Practices Act (1956), 4 \& 5 Eliz. II, c. 68, s. 21.

on S. 34(5) of the Act, added in 1960, provided that "no inference unfavourable to the person charged shall be drawn from such evidence if he satisfles the court that he a practice of using the articles for certain specified undesirable objectives. This need not mean that an unfavourable inference will be drawn in the absence of such evidence forwarded by the accused.

01 E.g., The King v. Beckett (1910), 15 C.C.C. 408, 449; R. v. Famous Players (1932), 58 C.C.C. $50,96$.

02 E.g. R. v. McGavin Bakeries Ltd. (No. 6) (1951), ve C.R. 63; R. v. Howard Smith Paper Mills Ltd. (1955), 22 C.R. 205 (reasonable doubt as an unsuccessful ground of appeal) R. v. Northern Electric Co. (1955), 21 C. R. 45; R. v. Abitibi Power and Paper Co. (1960), 36 C.R. 96. 
application by the courts, the principle is realistic or desirable for combines cases.

The entire context of combines situations is unique for rules of criminal law. The essential facts, such as meetings, prices, price changes, costs, and competitors are known to the court; and the sole issue is in essence whether a fusion of these established facts amounts to a crime. There is no agreed social detriment in relation to which the trial is directed to find responsibility in the party charged.

The cases yield a few indications of a compromise of the stringent criminal standard of proof. In Container Materials, the Supreme Court of Canada suggested that the nature of the direct object of the parties was a question of fact for the "common sense view" of the court. ${ }^{93}$ It appeared, for a time, that the "is likely to" language of the merger and monopoly offences was going to be read as importing the civil balance of probabilities test; but, for merger cases at least, this has now been rejected. ${ }^{94}$

The effect of section 41, with its phrase "shall prima facie be deemed," has already been mentioned. In Crown Zellerbach, ${ }^{95}$ the accused decided not to call evidence; and the Court held that on the evidence submitted, together with section 41 , the Crown had proven guilt beyond a reasonable doubt.

The standard of reasonable doubt appeared to figure largely in the two recent merger acquittals. ${ }^{06}$ Since criminality for mergers can depend upon the likely effects of the merger, and since the courts declare an aversion for economic data and theory as such, it is possible that the standard is more significant for merger cases than for conspiracy cases. In the latter, as a matter of evidence, the effects have usually been fully manifested before trial; and the court is reasoning back to the agreement. This is not to suggest that it is easier to infer an agreement than to find public detriment, but the former is closer to a legal question. Realities of evidence mean that "likely" effects are rarely a concern in conspiracy cases.

\section{Strict Construction}

While the principle of reasonable doubt relates to issues of fact, that of strict construction of a penal statute in favour of the accused concerns the interpretation of the law. Like many basic criminal principles in England and Canada, those principles relating to the method of interpreting criminal statutes have been developed by the courts. As with the concept of reasonable doubt, there is in the combines cases mention of the principle of construction. There is likewise, however, little protracted comment; and evaluation is difficult.

The pattern present in the Singer case is in point. Mr. Justice Wright in the Ontario High Court commenced with the following observation:

In attempting to arrive at its proper construction, one must keep in mind the rule of construction applicable to penal statutes and apply a strict construction to the same. ${ }^{97}$

93 R. v. Container Materials Ltd. (1942), 77 C.C.C. 129, 141. This was echoed in MeGavin Bakeries, ante, n. 92 at $92-93$.

94 See Bddy Match Co. v. The Queen (1953), 18 C.R. 357, 372; and R. v. Canadian Breweries Ltd. (1960), 33 C.R. $1,27$.

95 R. v. Crown Zellerbach Canada Limited (No. 2) (1956), 22 C.R. 1, 3.

96 Canadian Breweries, ante, n. 94; and B.C. Sugar, ante, n. 80.

97 R. v. Singer, (1931), 56 C.C.C. 68, 71. 
He then proceeded to apply the plain-meaning rule and ordinary dictionary definitions to find the meaning of the statute. The accused were convicted.

Occasionally, the court will apply a rigourously strict construction against the Crown. In the unreported decision by His Honour Judge Currey in $R$. v. Cooper Campbell, (County of York, 1962) a sales agent of surgical blades was held not to be a "dealer" within section 34, and was acquitted. Section 34 (1) defines a dealer as "a person engaged in the business of manufacturing or supplying or selling any article or commodity." This decision has been reversed by the Ontario Court of Appeal.": The case is presently on appeal to the Supreme Court of Canada.

The proper rule of construction of penal statutes does not, indeed, require an ultra-strict construction; and it was more correctly stated by the Alberta Court of Appeal in R. v. Imperial Tobacco Co.:

It is a time-honoured rule of construction of penal statutes that they should be given a construction, so far as legitimate, most favourable to the subject.99

The difficult point in assessing the operation of the principle is the evaluation of the "legitimacy" of the application. It does not appear, however, especially since "undueness" is a question of fact, that the rule of strict construction presents serious problems in those sections of the Act which define the substantive offences.

\section{Intent}

It is not the concern of the writer in this paper to rehash existing discussions about the role and significance of mens rea and actus reus down through history to their changing meaning in our twentieth century welfare state. Suffice it to say that the general rule in the nineteenth century was that an act was not guilty unless the mind was also guilty; and, while this remains a strong general principle of criminal law, certain erosions have taken place. Substantive criminal law in Canada is solely statutory, and the mens rea requirement is only that mental element demanded by the relevant statute. Normally, in cases of silence in the statute, subjective intention is regarded by the courts as a requisite element of the offence; but experience indicates that a concept of risk may be invading the criminal law from several sides. ${ }^{100}$ An analysis of the combines cases illustrates developments in that direction.

Criminal conspiracy is, of course, one of the "inchoate" crimes; the crime consists in the agreement alone. Power to implement an agreement or the actual effects of implementation are relevant only as bases for an inference of the intent to enter an agreement or of the agreement itself, as the case may be. In theory, the offence goes beyond mere parallel

\footnotetext{
98 (1964), 46 D.L.R. (2d) 83.

99 (1942), 77 C.C.C. 146, 150-51. This view of the traditional principle is supported in Williams, Criminal Law, The General Part 217 (1961). A recent Supreme Court of Canada case approved the following summary by Halsbury:

It is a general rule that penal enactments are to be construed strictly, and not extended beyond their clear meaning. At the present day, this general rule means no more than that if. after the ordinary rules of construction have first been applied, as they must be, there remains any doubt or ambiguity, the person against whom the penalty is sought to be enforced is entitled to the benefit of the doubt.

See Winnipeg Film Society v. The Queen (1964), 44 D.L.R. (2d) 126, 131. For a similar See Winnipeg Film Society v. The Queen (1964), 44 D.L.R. (2d) 126, 131. For a similar
view in a combines case of the principle as developed, see R. v. Crown Zellerbach Canada Limited (1955), 21 C.R. 94, 101.

1 no See Mewett. The Shifting Basis of Criminal Law (1963), 9 McGill L.J., 124.
} 
intentions and requires an agreement. ${ }^{101}$ Entering the agreement is the actus reus of the conspiracy offence.

Overt acts resulting from performance of the agreement usually constitute independent crimes, although such is not the case under section 32 of the Combines Investigation Act. A combines conspiracy is an agreement or arrangement to do a lawful thing by unlawful means. There must be some element of intent and also an undue restriction. The issue is whether the undueness concerns only the effects of the agreement the parties intended to enter, or goes also to the quality of the intention.

The early cases required the purpose of the agreement to be undue; ${ }^{102}$ and, indeed, such a moralistic tone prevailed that, in Beckett, ${ }^{103}$ good motives were confused with purpose, and an acquittal was awarded. In 1912, Weidman v. Shragge, in the Supreme Court of Canada, began the emphasis upon commercial effects of the agreement as the sole revelant context for "undueness." The view that intent was irrelevant, other than the intent to enter an agreement, was re-enforced in Dominion Supply. ${ }^{104}$ Both of these latter cases were civil cases, but their principles have been adopted for criminal cases as well. In some cases it is unclear, and perhaps not important, whether the critical evil was the purpose, the power, the effect, or a combination of these. Overt acts can be a basis for an inference of wrongful intent, and are considered relevant to sentence. ${ }^{105}$

The leading case on the role of intention in the combines offence is Container Materials. In the Ontario Court of Appeal Mr. Justice Masten expressed the view that

In a charge of conspiracy all that is necessary to show mens rea is to show advertence in becoming a party to the conspiracy. ${ }^{106}$

In context, this meant that the intent did not have to be to enter into an agreement to restrict unduly, but only to enter into an agreement. His Lordship appeared to be influenced by the fact that the statute in issue in A.-G. Australia v. Adelaide S.C. Co. ${ }^{10 i}$ specifically required a showing of intent to cause the effects, whereas the Canadian legislation did not.

The majority judgment in the Supreme Court of Canada endorsed the view of Mr. Justice Masten:

Mens rea is undoubtedly necessary but that requirement was met in these prosecutions when it was shown that the appellants intended to enter, and did enter, into the very arrangement found to exist. ${ }^{10 \mathrm{~s}}$

101 This issue has yet to be settled in Canadian combines law. The cases in the United States hold that conscious parallelism alone is insufficient to constitute the crime: Theatre Enterprises, Inc. v. Paramount Films Distributing Corp (1954), 346 U.S. 537. The policy of combines enforcement in Canada, indicatively, is to treat identical tenders as "neutral facts" in the absence of proven arrangements. See D. H. W. Henry. "Unfair Distribution and Pricing Practices," in Trade Competition, U.C.L.S., Speclal Lectures, 1963, Vol. II, pp. 30-32.

102 The King v. Elliott (1905), 9 C.C.C. $505,509$.

103 The King v. Beckett (1910), 15 C.C.C. 408.

104 Dominion Supply Company v. T. L. Robertson Manufacturing Co. Ltd. (1917), 39 O.L.R. 495, 510.

105 See R. v. Canadian Import Co. (1933), 61 C.C.C. 114, 149; Belyea v. The King, [1932] S.C.R. 279; R. v. Howard Smith Paper Mills Ltd. (1957), 26 C.R. 1, 26.

106 R. v. Container Materials Ltd. (1941), 76 C.C.C. $18,63$.

107 [1913] A.C. 781 (P.C.).

108 (1942). 77 C.C.C. 129, 140. This is the view of the law adopted by the present Director of Investigation and Research. See Henry, ante, n. 101 at 27. 
The Supreme Court then proceeded to say, confusingly:

- any party to an arrangement, the direct object of which is to impose improper, inordinate, excessive or oppressive restrictions upon that competition, is guilty of an offence. 100

This does not, of course, mean that such an intent is necessary for the offence; and the case establishes the proposition that the requisite intent need relate only to entering the arrangement, regardless of evaluation of the intended effect. This is really only that mental element usually comprended by the concept of actus reus involving, as it does, a voluntary and deliberate act. The undueness, which is the other element of criminality, is determinable objectively as a question of fact from an analysis of the effects. ${ }^{110}$ Alternatively, since power to implement the agreement is not essential to the offence, an intention to limit unduly, if framed in an agreement to that end, would in theory be an offence.

It may well be that any distinctions between intent and effects are academic. On the one hand, agreements are usually only discovered once their effects are felt; and, on the other, the courts have found it very easy to reason from effects to a concomitant intent. Despite assurances that the criminal principles as laid down in Woolmington ${ }^{111}$ govern in combines cases, ${ }^{112}$ we find one of these basic principles overthrown by the Ontario Court of Appeal in the Electrical Contractors case:

The acts done by a person and the consequences thereof afford most cogent evidence of his intention. It is presumed that a person intends the natural consequences of his acts. ${ }^{113}$

This statement represents a critical proposition, since it permits questions of reasonable doubt and intent to be handled by a survey of such effects as may be gathered from the evidence. Since overt acts can be used as a basis for an inference of intent, the courts are able, with the presumption in Electrical Contractors, to determine guilt by an analysis of commercial effects. The presumption affects the question of subjective intent by reason of the use of an objective test. This type of reasoning has recently given rise to considerable comment in relation to the law of murder. ${ }^{114}$ Concern over the quality of subjective intent in combines cases may seem somewhat out of place, but perhaps it is the entire law of combines that is out of place.

\section{Trial by Jury}

An institution dating roughly from the thirteenth century, the jury became closely associated with the concept of criminal justice; and until 1949 it was available to anyone accused under the combines legislation in

109 Container Materials, id. at 141. See ante, n. 93, for the standard of proof for the "direct object."

110 Id., at 134, per Duff, J. This is the position taken in R. v. McGavin Bakeries Ltd. (No. 6) (1951), 13 C.R. 63, 93; R. v. Northern Electric Co. (1955), 21 C.R. 45. A rejection of this view of "unduly"" as a matter of law, by the trlal judge in $R$. v. Howard Smith Paper Mills Ltd. (1954), 19 C.R. 1, cannot be accepted as authoritative.

111 Woolmington v. D.P.P., [1935] A.C. 462. See especially p. 480 where Viscount Sankey, L.C., says:

. . If it is proved that the conscious act of the prisoner killed a man and nothing else appears in the case, there is evidence upon which the jury may, not must, find him guilty of murder.

112 R. v. Northern Electric Co. (1955), 21 C.R. 45, 47 per McRuer, C.J.H.C.

113 R. v. Electrical Contractors Association of Ontario (1961), 131 C.C.C. $145,163$.

114 See, particularly, Bradley v. R., [1956] S.C.R. 723; and D.P.P. v. Smith, [1960] 3 All E.R. 161 (H.L.) 
Canada. As of that year, by statutory amendment, ${ }^{115}$ it has not been available to accused corporations. Where an indictment is found against an individual, however, he may elect to be tried with a jury. Two exceptions to this right exist. Section 41 (2) does not permit a jury if the trial is in the Exchequer Court, and section 31 (4) does not permit a jury in proceedings under that section for an order of prohibition or dissolution.

It may well be asked whether twelve good men and true can have the comprehension of the facts and issues, complex as they generally are in modern combines litigation, to play any role whatever. It may be asked, in view of the complicity of an officer in the same conspiracy as the corporation for which he works, whether it is realistic to permit a jury trial for one and not for the other. The reasons for the existing law probably include an irrational prejudice against corporations, and the availability of the penalty of incarceration against an individual. Juries are expensive in the protracted nature of combines litigation, and this element would naturally militate against any policy of charging individual officers. It is not a case of juries having proven their worth in combines cases. ${ }^{116}$ The fact issues are economic. There is no difficult question of any culpable intent to be decided. Another relevant consideration is that, if an officer is tried by his peers-that is, by people who can understand the complexities and implications of business-and if the pre-trial publicity has had its designed effect, useful and competent jurors may well be disqualified by bias engendered by the "trial by government." Furthermore, the offence for which a jury would ostensibly be the most qualified to decide, namely, "materially misleading representation to the public" under section $33 C(1)$, is the only summary offence created by the combines legislation; and in relation to that a jury can play no role whatever. Therefore, even if the criminal law is to be retained as the appropriate device for the control of competition, it seems that the institution of the criminal jury no longer has a function in such a field.

\section{Previous Legal Advice}

In view of the uncertainty and lack of specificity in the law, prudent businessmen will seek legal advice to guide the arrangement of their affairs in such a way that they will not be regarded undue or to the public detriment. For the present, we may disregard any deliberate campaign to commit offences and to keep them secret.

Undueness is a question of fact; and it may be argued that, if a company acts under a legal opinion that no combines offence is being committed, it acts under a bona fide mistake of fact. There are obvious problems in making such an element as legal advice relevant to liability

116 (Can.) 1949 (2nd sess.), c. 12, s. 2. This has been upheld constitutionally by $R$. $v$. McGavin Bakeries Ltd. (No. 3) (1951), 12 C.R. 123 (S.C. Alta.). In R. v. Hobbs Glass Ltd., [1950] O.W.N. 368, the High Court of Ontario rejected an argument that the procedural provisions of the Code only applied after the corporation had had an election to be tried with or without a jury.

110 They are infrequently used, but have not been successful. In $R$. v. Imperial Tobacco Co. (1942), 77 C.C.C. 146 (Alta. C.A.), a fifty-five day trial was nullified and ordered to be retried, due to an error in handling the jury. In $R$. $v$. Morey (1957), 24 C.R. 319, a conviction after a twenty-two day trial was quashed because of an error in charging the jury.

the jury. Un the United States, criminal antitrust trials frequently take place before a jury. A jury may, however, be waived with the consent of both parties and the permission of the court. See Dobey. "Criminal Antltrust Trlals", 4 A.B.A. Antitrust Section Report 49, 58 (April, 1954). 
or sentence. Companies must not be induced to shop around until they acquire favourable legal advice; and the court, obviously, cannot undertake an inquiry into the competence or bona fides of the advice given. ${ }^{117}$ Also, if the advice is unfavourable, a litigation privilege may well keep it out of court even if a written opinion were uncovered. On the other hand, in the uncertainty of the combines law, companies can only act upon their legal advice.

The cases have held that legal opinions are inadmissible in evidence as showing an absence of intent to act outside the law. The leading case is Container Materials, where the holding in this respect was concomitant with the view there taken of the nature of mens rea in a combines offence. The view of the trial judge, as affirmed, in ruling against the admissibility of the legal opinion was:

I cannot, however, hold that the seeking or obtaining of such advice, whatever the nature of such advice may have been, is evidence of lack of mens rea. Mens rea cannot be based on such type of evidence alone, but may be found in the general situation and overt acts of the accused.11s

Legal advice, if relevant at all, is tendered to show that the accused acted in a belief that he was within the law, but it goes to questions of fact. There is no issue of ignorantia juris.

Many of the same practical problems attending the use of legal opinions to determine responsibilty likewise apply in relation to its materiality as a sentencing factor. Yet, courts occasionally consider the fact of legal opinions when deciding on sentence. ${ }^{119}$ Harsh as it may seem in some instances, a preferable view would exclude previous legal opinions as a sentencing consideration. Any reliance upon opinions is capable of creating an unfair sentence disparity, and operates as a negative penalty upon those who did not first seek out favourable legal advice. Obtaining legal counsel in combines matters may well be a prudent business procedure, but it would be unwise to place an obligation upon anyone to seek it before acting. The argument against this view is, of course, that the potential of any deterrent value in the sentence depends upon the absence of mistake. It is another of those dilemmas posed by the use of the criminal law in combines control. By inferring an undue intent from undue effects, the court arrives at a totally artificial result, and the sentence is similarly artificial and misguided.

\section{CONCLUSIONS}

This paper has attempted to indicate how the traditional concepts of the criminal law have been strained in the attempt to adapt them to twentieth century commerce and forms of business organization. The demands of 1889 are not the demands of the 1960's, and the combines

117 Yet, in his dissent in R. v. Master Plumbers (1907), 12 C.C.C. 385, 395, Meredith, J.A., regarded as relevant that the companies acted under the "competent legal advice... of reputable lawyers.'

In Belyea v. The King, [1932] S.C.R. 279, 286, Chief Justice Anglin reproached the lawyer who had advised the accused and said ". . he rather gloried in the attempt so made to evade the law." Incidentally, the lawyer was the one who had been retained by the Canadian Government to conduct its case in In re The Board of Commerce Act (1920), 60 S.C.R. 456 .

118 R. v. Container Materials Ltd. (1940), 74 C.C.C. 113, 126.

119 See The King v. Elliott (1905), 9 C.C.C. 505, 513, and R. v. McGuire (1906), 7 O.W.R. 225. 227, where suggestions as to form are set out. More recent and more ambiguous instances include the unreported judgments on sentence by $\mathrm{Mr}$. Justice Lazure in 1958 (Que. Q.B., Crown Side), in R. v. Bathurst Pulp and Paper Company, and in R. v. Gair Company of Canada Lim:ted. 
cases illustrate the contortions through which the courts have been going in their attempts to accommodate the change absent any fundamental overhaul of the statute. The object of the statute has changed, and increasingly the control of combines is recognized as a sophisticated problem requiring analysis of economic data. The Canadian courts, aware of their deficiencies in the training needed for such evaluations, resist as much as possible any debate over or inquiry into economic data or theory. ${ }^{120}$

The considerations of 1889 which impelled the legislators to make the combines law criminal no longer obtain. The undesirability of combines no longer stems appreciably from rejection on moral grounds; nor can the Act be specific in such a way as to bring combines offences within the other general category of moral element, as discussed in this paper. This is not to suggest that combines ought to be in one of the two categories; but only that, if it is not, the use of the criminal law as the appropriate control device must be seriously questioned.

The criminal sanction has not worked well in combines. The amounts of the fines levied are usually altogether too small to constitute a financial deterrent, and jail sentences have in no case been found appropriate. The sentencing principles are confused, and the function of publicity anomalous. The newer prohibition orders appear to be of questionable effect at best, and at worst rest upon tenuous constitutional grounds.

Several emblems of the criminal process have been compromised in order to introduce some realism to combines control through the criminal law in the courts. The burdens upon the Crown have been relaxed and those upon the accused increased, in order to find undueness beyond a reasonable doubt. The traditional requirement of guilty intention has become meaningless.

Problems of morality, substantive theory, and effective enforcement are presented in other areas of criminal law; but nowhere else is there the concentration of these stresses, along with the unique nature of the public interest, that is presented by the combines offence and offender. The strain placed upon the criminal law by problems of competition is reflected in the attempts by criminologists to apply their regular tools to a meaningful concept of white collar crime. For example, who is the recidivistthe corporate name, the president, the board of directors, the most influential board member, the holding company? What are the problems of intra-enterprise conspiracy and of interlocking directorates? Criminology is that socio-legal science that mirrors the scope of the criminal law. Its problems reflect real problems in the use of the criminal law as a device for the control of competition.

120 See Oppenheim, Federal Antitrust Legislation: Guideposts to a Revised National Antitrust Policy (1952), 50 Mich. L. Rev. 1139, 1161 ff. Appreciating the necessity of taking cognizance of economic data and economic problems, Professor Oppenhelm prefers that, for domestic antitrust problems, this be done by the resular courts rather than by removing antitrust to a specialized tribunal. The views expressed in his article generally found sympathy in the Report of the Attorney-General's National Committee to Study the Antitrust Laws, 1955. This is, essentially, the approach to economic problems now taken by the American courts. Its development may be traced, for our purposes, through the cases of Standard Oil of California and Standard Stations, Inc. v. United States, (1949), 337 U.S. 293; United States v. E. I. duPont de Nemour nnd Co. (1956), 351 U.S. 377; and Brown Shoe Co. Inc. v. United States (1962), 370 U.S. 294. The Federal Trade Commission also is much more of a regulatory tribunal (and is designed as such) than any of the combines agencies in Canada. 
In past years there have been evaluations, implicitly by Parliament and more specifically by the judiciary, of the propriety and efficacy of the criminal law in combines. For seventy years Parliament has, by piecemeal legislation, attempted to improve the workability of the statute; and, in so doing, has created the present hybrid which yet does not perform the job to be done. The judiciary has been more openly critical. ${ }^{121}$

The disadvantages of the present system are not all commercial. The criminal law can only be detrimentally affected if effective and efficient means of detection and prevention of offences are not available. These necessities tie in with public acceptance of the law, and with its speedy and just enforcement in the courts.

The normal contacts which a corporation makes with law and government are in the areas of taxation, corporate structure, and corporate finance. The statutes in these areas are specific, and there is nothing legally or morally wrong with arranging one's affairs to one's best advantage within such statutes and regulations. The Combines Investigation Act, however, is vague and non-specific. The cases indicate that there is more to counselling an enterprise on combines matters than merely basing one's advice upon the statute and the facts of decided cases. The cases suggest that there is a "spirit" also to combines law, which possibly derives partly from the very vagueness of the proscription and from the reasons compelling that lack of particularity.

Commercial efficacy depends upon some ability to appreciate one's legal position; and it is not to be wondered that in cases of doubt, which are many in the field of combines, there is a natural tendency to take some precautions to escape notice. Many things appear to work against any scientific attempt to stay within the combines laws. The practical effect can only be to restrain commerce when it should be forging ahead, by restricting a wider range of activity than might actually be proscribed by the law.

There is really nothing wrong with undueness and public detriment as tests; but their meaning can only be realistically defined in economic, not legal, terms. Somehow, the available expertise must be utilized.122 Some sort of a specialized tribunal may be thought necessary. Such a fragmentation of adjudicative agencies along functional lines is now a well-recognized twentieth century phenomenon, made necessary by increasing complexity of social organization.

Has the criminal law any function or value whatever in the control of competition? Certainly, it can only be used realistically in areas for which it was designed. The criminal penalty ought only to lie for breach of a specific order; and generally it should be restricted to natural persons, since the deterrent value and the fact of conviction work most effectively when humanized. Provable wilfulness which is blameworthy, such as that which characterizes the field of deceptive trade practices,

121 See the remarks of Mr. Justice Rand in R. v. Goodyear Tire and Rubber Co., [1956] S.C.R. 303,311 .

122 In 1960, section 41A was added to the Act, to permit a prosecution to take place in the Exchequer Court if the accused consented. One of the reasons given by the Minister of Justice for this amendment was that settlement would be faster, and a skilled body of combines jurists could also be bult up. His other reasons implicitly recognize several weaknesses of the criminal law, for this purpose, mentioned elsewhere in the paper. See Proceedings of the Senate Standing Committee on Banking and Commerce, August 3 and 4,1960, pp. 92-96. 
may also be appropriate for effective proscription by the criminal law; but an intent to act wrongfully or in contravention of the statute should be capable of decisive demonstration.

This paper has been largely negative in character, but the first step in any process of reform must be to evaluate current procedures in order to discover and to articulate any shortcomings. It is a second step which concerns the consideration of alternative forms of control. These are legion in the field of combines, and many have been developed in other jurisdictions. While Canada admittedly faces unique constitutional difficulties, the superior plan of attack is first to select the most desirable controls, and then to attempt to justify them constitutionally. It may well be that the criminal law will retain a meaningful position in a revised scheme, and indeed this is most likely; but it must also be co-ordinated with new modes of administration. 